\title{
Synergy of methanolic leave and stem-back extract of Anacardium occidentale L. (cashew) against some enteric and superficial bacteria pathogens
}

\begin{abstract}
The synergy of methanolic leave and stem-back of Anacardium occidentale (Cashew) against some enteric (Escherichia coli) and superficial (Staphylococcus aureus) bacteria pathogens was investigated. The stem-bark and leaves of Anacardium occidentale were dried, extracted using methanol and evaluated for sensitivity using agar well diffusion method. The zone of inhibition for leaves, stem-bark and synergy (leaves+stem-bark) was $9.67 \mathrm{~mm}, 12.00 \mathrm{~mm}$ and $12.33 \mathrm{~mm}$ respectively for Escherichia coli; and $11.33 \mathrm{~mm}, 13.67 \mathrm{~mm}$ and $14.00 \mathrm{~mm}$ respectively for Staphylococcus aureus. The synergy extract had superior effects for both test organisms. Hence, there is the need for research to focus on the isolation and purification of the bioactive ingredients of the plants that enable them has antibacterial activities.
\end{abstract}

Keywords: anacardium occidentale, antibacterial, bacteria pathogens, methanol, medicinal plants
Volume 4 Issue 3 - 2018

\author{
Sylvester Chibueze Izah,' EJ Uhunmwangho, ${ }^{2}$ \\ Kingsley Excel Dunga, ${ }^{3}$ Lovet T Kigigha' \\ 'Department of Biological Sciences, Niger Delta University, \\ Nigeria \\ ${ }^{2}$ Department of Medical Laboratory Science, Ambrose Alli \\ University, Nigeria \\ ${ }^{3}$ Department of Medical Laboratory Science, Madonna \\ University, Nigeria
}

\begin{abstract}
Correspondence: Sylvester Chibueze Izah, Department of Biological Sciences, Faculty of Science, Niger Delta University, Wilberforce Island, Bayelsa state, Nigeria,

Email chivestizah@gmail.com
\end{abstract}

Received: May 21, 2018| Published: June 07, 2018

\section{Introduction}

Several groups of microorganisms have been implicated with gastrointestinal disorder. Among these bacteria is Escherichia coli which have been severally studied. ${ }^{1-5}$ Kigigha \&Zige, ${ }^{6}$ Kigigha et al., ${ }^{3}$ reported that Escherichia coli and Staphylococcus aureus as indicators for enteric and superficial disease causing agents respectively. Typically, the occurrence of enteric pathogens in ingestible items such as food and water is among the main cause of diarrhea and dysentery especially in developing nations. ${ }^{1}$ These organisms have been widely reported in several food items including gari, ${ }^{7}$ suya,${ }^{8}$ ground nut, ${ }^{9}$ palm oil, ${ }^{10-13}$ slice fruit (paw-paw, water melon, pineapple),${ }^{14}$ meat pie, ${ }^{15}$ smoke fish, ${ }^{16}$ potable water sources. ${ }^{17-19}$ Instances of antibiotics resistance is a major issues in the field of pharmaceutical science. ${ }^{20-26}$ Among the common organisms that confers resistance to antibiotics is Staphylococcus aureus. ${ }^{1}$ According to Nwinyi et al., ${ }^{1}$ infections associated with methicillin resistant Staphylococcus aureus and vancomycin resistant Staphylococcus aureus tend to cause high morbidity and mortality, and also increase treatment cost.

Probably due to the challenges of drug resistance and emerging and re-emerging microbial infections, the search for new antibodies has increased. ${ }^{24-26}$ Globally, plant resources is used for the treatment of several diseases especially by individuals residing in rural areas in many developing countries. ${ }^{8,14,22}$ Medicinal plants have been widely described as plants whose one or more parts have therapeutics properties against diseases including bacterial diseases. ${ }^{20-25,27}$ The medicinal potentials of plants is associated with their secondary metabolites such as tannins, terpenoids, alkaloids, flavonoids, etc. they contain. ${ }^{27-29}$ Scientific validations have been made with some of the claims of traditional medicine practitioners, but many others claims need to still be studied. Also there is the need for isolation and purification of exact chemical constituent that make plant confers pharmacological properties.
Anacardium occidentale L. which belong to the Anacardiaceae family is one of the plant species that are used by traditional medicine practitioners for the treatment of different diseases. The plants can growth up to $15 \mathrm{~m}$ in height in the tropics and tropical rain forest. ${ }^{30}$ Traditionally, the parts of Anacardium occidentale are used for preparing several medicine in different regions of the world. Agedah et al., ${ }^{30}$ reported that Anacardium occidentale is used for the treatment of diarrhoea, dysentery, stomach ulcer in Ghana, Nigeria, Togo; eye and ear infections in Africa and Brazil; wound healing, malaria and prevention of bleeding in Africa; antidiabetic in Ghana, Haiti, Kenya, Mexico, Nigeria; and treatment of fever, poisoning, warts, toothache in Haiti, Turkey. The authors further reported that the plant also has antibacterial, antiseptic, Anti-diabetic, anti-inflammatory activities, and it also promotes blood coagulation. Furthermore, different parts of Anacardium occidentale including bark, stem, and leaf extracts, have antimicrobial, ${ }^{31-36}$ antidiabetic ${ }^{37}$ and anthelminthic potentials. ${ }^{38}$

Among the antimicrobial potentials of Anacardium occidentale using different solvents for extraction, information about the synergy of stem-bark and leaves methanolic extracts against some microbes that causes gastrointestinal and superficial infections is scanty in literature. Hence, this study aimed at assessing the synergistic efficacy of methanolic stem-bark and leaves extracts of Anacardium occidentale against Escherichia coli and Staphylococcus aureus.

\section{Materials and methods}

\section{Samples preparations and extraction}

Fresh stem-bark and leaves Anacardium occidentale used for the study were washed with distilled water. The water was allowed to drain off. The samples were shade dried and then chop into small pieces with knife. The samples were then blended independently using Binatone blender. $40 \mathrm{~g}$ of the powdered samples were soaked in $100 \mathrm{ml}$ of methanol for 48 hours, ${ }^{39}$ while mixture of stem-bark and 
leaves (1:1 ratio) was soaked in methanol for 48 hours as well. ${ }^{26,39}$ After 48 hours, they were filtered with muslin cloth, and the resultant filtrate was re-filtered using Whatman filter paper. ${ }^{26,39}$ The solvent were allowed to evaporate in a water bath.

\section{Isolates characterization}

Staphylococcus aureus and Escherichia coli used for the study were obtained from Medical Microbiology units, Federal Medical Centre, Yenagoa, Bayelsa state, Nigeria. The characteristics of the bacteria isolates were determined following the scheme provided by Cheesbrough. ${ }^{40}$

\section{Antimicrobial screening of the extract}

The zone of inhibition was determined using Agar well diffusion techniques that was previously described by Lino \& Deogracious ${ }^{41}$ cited in Doherty et al., ${ }^{42}$ with slight modification by Agu \& Thomas, ${ }^{43}$ Kigigha et al., ${ }^{22,33}$ Epidi et al.,, ${ }^{20,21}$ Izah et al., ${ }^{25,26}$ Izah \& Aseibai., ${ }^{39}$ Nutrient agar was used as the agar medium; the medium prepared according to manufacturers' instruction was dispensed onto sterile petri dish and which was allowed to solidify. Approximately $0.3 \mathrm{ml}$ of 24 hours incubated isolate in peptone water was spread over the surface of the agar. A total of 3 wells of $6 \mathrm{~mm}$ in diameter were made in each agar plate and $0.3 \mathrm{ml}$ of the extracts was dispensed into the agar wells. The medium were incubated at room temperature for 24 hours and the resultant zones of inhibition were measured.

\section{Statistical analysis}

The mean were calculated and the resultant values were used to plot the chart using Microsoft excel.

\section{Results and discussion}

The zone of inhibition of methanolic leaves and stem-bark of Anacardium occidentale against superficial (Staphylococcus aureus) and enteric (Escherichia coli) bacteria agents is presented in Figure 1. The zone of inhibition for leaves, stem-bark and synergy (leaves+stem-bark) was $9.67 \mathrm{~mm}, 12.00 \mathrm{~mm}$ and $12.33 \mathrm{~mm}$ respectively for Escherichia coli; and $11.33 \mathrm{~mm}, 13.67 \mathrm{~mm}$ and $14.00 \mathrm{~mm}$ respectively for Staphylococcus aureus. The result showed that the leaves confer superior effect against Escherichia coli, while the stembark has apparent higher effect against Staphylococcus aureus. The synergy extract had superior effects for both test organisms. The parts of Anacardium occidentale have been reported to have antimicrobial potentials against several types of microbes. The antimicrobial potentials of Anacardium occidentale could be due to the presence of several phytochemical and bioactive constituents. Oviasogie et al., ${ }^{27}$ reported that ethanolic stem stick of Anacardium occidentale contain alkaloids, steroids, saponins, tannins, flavonoids, carbohydrate, while the aqueous extract of small part of the plant contain glycosides. Ojezele and Agunbiade ${ }^{44}$ reported that aqueous (hot and cold water) and methanol extracts of leaf, bark and root of cashew contain tannin, total polyphenol, oxalate, saponin and alkaloid. Agedah et al. ${ }^{30}$ reported that antimicrobial potentials of Anacardium occidentale could be due to the presence of anacardic acid-a polyphenol and other compounds such as tatrols and tannins. ${ }^{30}$

The findings of this study had some similarity with the work of other authors. Wonghirundecha and Sumpavapol ${ }^{45}$ reported that leaves of Anacardium occidentale have inhibitory activities against Escherichia coli and Staphylococcus aureus. Aderiye \& David ${ }^{36}$ reported that hot water extracts of cashew apple peels have inhibitory effectiveness against Escherichia coli O157:H7 and methicillin resistant Staphylococcus aureus. Typically, slight variation occurred among both type of organisms as well as the extracts. The variation in sensitivity could be due to the gram reaction of both organisms s, $^{25,30,36,46}$ thus Staphylococcus aureus (gram positive) and Escherichia coli (gram negative). Agedah et al., ${ }^{30}$ reported that gram positive bacteria lack an outer membrane in their cell walls which gram negative bacteria do possess. The authors further reported that outer membrane (which could hinder substantial amount of the extract from having contact with the cell wall) could be responsible in variation in the level of sensitivity of the extract. In additions, authors have variously reported that sensitivity of plant extract could be determined by the nutrition, physiology, metabolism and biochemistry of the isolates, age of the plant, extraction solvent, plant parts and concentration of the extracts. ${ }^{20-26,28,29,39}$

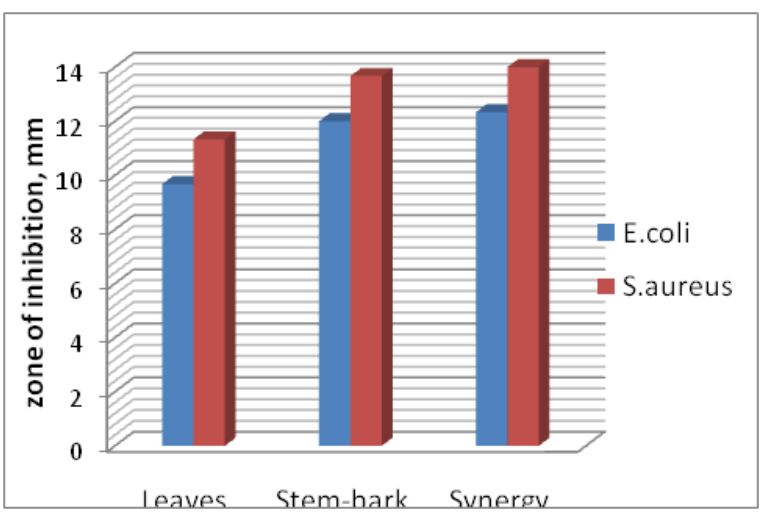

Figure I Zone of inhibition of methanolic leaves and stem-bark extract of Anacardium occidentale against some superficial and enteric bacteria pathogens.

\section{Conclusion}

This evaluated the synergistic potency of methanolic stem-bark and leaves of Anacardium occidentale against Escherichia coli and Staphylococcus aureus. The showed that methanolic stem bark and leaves extract of Anacardium occidentale confers sensitivity against Escherichia coli and Staphylococcus aureus. In addition, the synergy resulted has slight higher effects compared to the individual extracts.

\section{Acknowledgments}

None.

\section{Conflict of interest}

The author declares that they have no competing interests.

\section{References}

1. Nwinyi OC, Chinedu NS, Ajani OO. Evaluation of antibacterial activity of Pisidium guajava and Gongronema Latifolium. Journal of Medicinal Plants Research. 2008;2(8):189-192.

2. Kigigha, LT, Apreala A, Izah SC. Effect of cooking on the Climbing Pepper (Piper nigrum) on Antibacterial Activity. Journal of Environmental Treatment Techniques. 2016;4(1):6-9.

3. Kigigha, LT, Izah SC, Prebo PE. Effect of Residual Antibiotics in Snacks against Escherichia coli and Staphylococcus aureus. Journal of Environmental Treatment Techniques. 2015;3(4):201-203. 
4. Kigigha LT, Atuzie MN. Assessment of traditional medicinal application of Alchornea cordifolia. African Journal of Biotechnology. 2012;11(8):2083-2086

5. Kigigha LT, Charlie EJ. Effect of pepper-soup cooking on the antibacterial activity of Monodora myristica. Continental J Food Science and Technology. 2012;6(1):8-11.

6. Kigigha LT, Zige DV. Activity of Chromolaena Odorata on enteric and superficial etiologic bacterial agents. American Journal of Research Communication. 2013;1(11):266-276.

7. Kigigha LT, Izah SC, Kpea TB. Microbiological quality of fermented Cassava Flakes (Gari) sold in Yenagoa, Metropolis, Nigeria. Bulletin of Advanced Scientific Research. 2015;1(7):157-160.

8. Kigigha LT, Ovunda HO, Izah SC. Microbiological quality assessmen of suya sold in Yenagoa Metropolis, Nigeria. Journal of Advances in Biological and Basic Research. 2015;1(5):106-109.

9. Kigigha LT, Igoya UOS, Izah SC. Microbiological Quality Assessment Of Unpeeled Groundnut Sold in Yenagoa Metropolis, Nigeria. International Journal of Innovative Biochemistry \& Microbiology Research. 2016;4(4):1-22.

10. Izah SC, Ohimain EI. Microbiological quality of crude palm oil produced by smallholder processors in the Niger Delta, Nigeria. Journal of Microbiology and Biotechnology Research. 2013;3(2):30-36.

11. Ohimain EI, Izah SC. Physicochemical characteristics and microbia population of palm oil sold in major markets in Yenagoa metropolis, Bayelsa States, Nigeria. Journal of Environmental Treatment Techniques. 2015;3(3):143-147.

12. Ohimain EI, Izah SC, Fawari AD. Quality assessment of crude palm oil produced by semi-mechanized processor in Bayelsa state, Nigeria. Discourse Journal of Agriculture and Food Sciences. 2013;1(11):34- 46.

13. Seiyaboh EI, Kigigha LT, Alagoa CT. Microbial Quality of Palm Oil Sold in Amassoma, Bayelsa State, Nigeria. Int J Pub Health Safe. 2018;3:153.

14. Izah SC, Aseiba ER, Orutugu LA. Microbial quality of polythene packaged sliced fruits sold in major markets of Yenagoa Metropolis, Nigeria. Point Journal of Botany and Microbiology Research. 2015;1(3):30-36.

15. Kigigha LT, Berezi J, Izah SC. Bacteriological Quality Assessment of Meat Pie Sold in Yenagoa Metropolis, Nigeria. EC Nutrition. 2017;6(6):189-195.

16. Ineyougha ER, Orutugu LA Izah SC. Assessment of Microbial Quality of Smoked Trachurus trachurus sold in some Markets of Three South-South States of Nigeria. International Journal of Food Research. 2015;2:16-23.

17. Izah SC and Ineyougha ER. A review of the microbial quality of potable water sources in Nigeria. Journal of Advances in Biological and Basic Research. 2015;1(1):12-19.

18. Seiyaboh, EI, Izah SC. Bacteriological assessment of a tidal creek receiving slaughterhouse wastes in Bayelsa state, Nigeria. Journal of Advances in Biology and Biotechnology. 2017;14(1):1-7.

19. Seiyaboh, EI, Izah SC, Bokolo JE. Bacteriological quality of water from river nun at Amassoma Axises, Niger Delta, Nigeria. ASIO Journal of Microbiology, Food Science \& Biotechnological Innovations. 2017;3(1):22- 26 .

20. Epidi JO, Izah SC, Ohimain EI. Antibacterial and synergistic efficacy of extracts of Alstonia boonei tissues. British Journal of Applied Science, 2016;1(1):21-26.

21. Epidi JO, Izah SC, Ohimain EI, et al. Antibacterial and synergistic potency of tissues of Vitex grandifolia. Biotechnological Research. 2016;2(2):69-76
22. Kigigha LT, Biye SE, Izah SC. Phytochemical and antibacterial activities of Musanga cecropioides tissues againstEscherichia coli, Pseudomonas aeruginosa Staphylococcus aureus, Proteus and Bacillus species. International Journal of Applied Research and Technology. 2016;5(1):100-107.

23. Kigigha LT, Izah SC, Ehizibue M. Activities of Aframomum melegueta Seed Against Escherichia coli, S. aureus and Bacillus species. Point Journal of Botany and Microbiology Research. 2015;1(2):23-29.

24. Izah SC, Uhunmwangho EJ, Eledo BO. Medicinal potentials of Buchholzia coriacea (wonderful kola). Medicinal Plant Research. 2018;8(5):27-43.

25. Izah SC, Zige DV, Alagoa KJ, et al. Antibacterial Efficacy of Aqueous Extract of Myristica fragrans (Common Nutmeg). EC Pharmacology and Toxicology. 2018;6(4):291-295.

26. Izah SC, Uhunmwangho EJ, Etim NG. Antibacterial and synergistic potency of methanolic leaf extracts of Vernonia amygdalina L. and Ocimum gratissimum L. Journal of Basic Pharmacology and Toxicology. 2018;2(1):8-12

27. Oviasogie FE, Ogofure AG, Beshiru A, et al. Comparative Evaluation of the Antimicrobial Activities of Cashew (Anacardium occidentale), Neem (Azadirachta indica), Guava (Psidium guajava) and Bitter-leaf (Vernonia amygdalina) chewing sticks and Herbal Toothpaste against Streptococcus mutans. Annals of Science and Technology -A. 2016;1(1):28-34.

28. Kigigha LT, Kalunta CG. Antimicrobial efficacy of leaf extracts of Piper nigrum against Escherichia coli, Staphylococcus aureus and Candida albicans. Journal of Basic Pharmacology and Toxicolog. 2017;1(2):3236.

29. Kalunta CG. Antimicrobial effect of different seed extracts of Piper nigrum against Escherichia coli, Staphylococcus aureus and Candida albican. Biotechnol Res. 2017;3(3):71-76.

30. Agedah CE, Bawo DDS, Nyananyo BL. Identification of antimicrobial properties of cashew, Anacardium occidentale L. (Family Anacardiaceae). J Appl Sci Environ Manage. 2010;14(3):25-27.

31. Varghese J, Tumkur VJ, Ballal V, et al. Antimicrobial effect of Anacardium occidentale leaf extract against pathogens causing periodontal disease. Advances in Bioscience and Biotechnology. 2013;4(8):15-18.

32. Akinpelu DA. Antimicrobial activity of Anarcardium occidentale bark Fitoterapia. 2001;72(3):286-287.

33. Chaithra M, Vivek MN, Asha MM, et al. Inhibitory effect of leaf and bark of Anacardium occidentale against clinical isolates of Staphylococcus aureus and Streptococcus mutans. Journal of Drug Delivery and Therapeutics. 2013;3(6);80-83.

34. Dahake AP, Joshi VD, Joshi AB. Antimicrobial screening of differen extract of Anacardium occidentale Linn. Leaves. Interdisciplinary Journal of Contemporary Research in Business. 2009;1;856-858.

35. Doss VA, Thangavel KP. Antioxidant and antimicrobial activity using different extracts of Anacardium occidentale L. International Journal of Applied Biology and Pharmaceutical Technology. 2011;2;436-443.

36. Aderiye BI, David OM. In vitro Antibacterial Activity of Aqueous Extracts of Cashew (Anacardium occidentale L.) Fruit Peels Using Bioautography Method. European Journal of Medicinal Plants. 2014;4(3):284-291.

37. Elaikum-Ikechukwu C, Bassey T, Ihentuge C. Effect of ethanolic stembark extract of Anacardium occidentale (Cashew) on the histology of the pancreas of diabetic wistar rats. Journal of Biology Agriculture and Healthcare. 2010;2(11):153-156.

38. Aiswarya G, Reza KH, Radhika G, et al. Study for anthelminthic activity of cashew apple (Anacardium occidentale) extract. International Journal of Pharmaceutical Sciences Review and Research. 2011;6(1):44-48. 
39. Izah SC, Aseibai ER. Antibacterial and Synergistic activities of methanolic leaf extract of Lemon grass (Cymbopogon citratus) and rhizome of Ginger (Zingiber officinale) against Escherichia coli, Staphylococcus aureus and Bacillus species. Acta Scientific Microbiology. 2018;1(6):26-30.

40. Cheesbrough M. District Laboratory Practice in Tropical Countries. $2^{\text {nd }}$ ed. England: Cambridge press; 2004.

41. Lino A, Deogracious O. The invitro antibacterial activity of Annonna senegalensis, Sacuridecae longipendiculata and Steganotaema araliacea. Uganda medicinal plants. Journal of African Health Science. 2006;6(1):31-35

42. Doherty VF, Olaniran OO, Kanife UC. Antimicrobial activities of Aframomum Melegueta (Alligator pepper). International Journal of Biology. 2010;2(2):126-131.

43. Agu GC, Thomas BT. Antibacterial Activities of Ethanol and Aqueous Extracts of Five Nigerian Medicinal Plants on Some Wound Pathogens. Nature and Science. 2012;10(2):78-84.
44. Ojezele MO, Agunbiade S. Phytochemical constituents and medicinal properties of different extracts of Anacardium occidentale and Psidium guajava. Asian Journal of Biomedical and Pharmaceutical Sciences. 2013;3(16):20-23.

45. Wonghirundecha S, Sumpavapol P. Antibacterial Activity of Selected Plant By-products Against Foodborne Pathogenic Bacteria. 2012 International Conference on Nutrition and Food Sciences. IPCBEE 39(2012)C(2012). Singapore: IACSIT Press; 2012.

46. Kigigha LT, Selekere RE, Izah SC. Antibacterial and synergistic efficacy of acetone extracts of Garcinia kola (Bitter kola) and Buchholzia coriacea (Wonderful kola). Journal of Basic Pharmacology and Toxicology, 2018;2(1):13-17. 